Kansas State University Libraries

New Prairie Press

\title{
A STATISTICAL MODEL USING REFERENCE EVAPOTRANSPIRATION AND WEATHER DATA TO PREDICT THE ECONOMIC OPTIMAL IRRIGATION LEVEL FOR CORN PRODUCTION IN THE TEXAS PANHANDLE
}

W. Arden Colette

Clay Robinson

Lal Khan Almas

Follow this and additional works at: https://newprairiepress.org/agstatconference

Part of the Agriculture Commons, and the Applied Statistics Commons (c) (1) $(9)$

This work is licensed under a Creative Commons Attribution-Noncommercial-No Derivative Works 4.0 License.

\section{Recommended Citation}

Colette, W. Arden; Robinson, Clay; and Almas, Lal Khan (2001). "A STATISTICAL MODEL USING REFERENCE EVAPOTRANSPIRATION AND WEATHER DATA TO PREDICT THE ECONOMIC OPTIMAL IRRIGATION LEVEL FOR CORN PRODUCTION IN THE TEXAS PANHANDLE," Conference on Applied Statistics in Agriculture. https://doi.org/10.4148/2475-7772.1214

This is brought to you for free and open access by the Conferences at New Prairie Press. It has been accepted for inclusion in Conference on Applied Statistics in Agriculture by an authorized administrator of New Prairie Press. For more information, please contact cads@k-state.edu. 


\title{
A STATISTICAL MODEL USING REFERENCE EVAPOTRANSPIRATION AND WEATHER DATA TO PREDICT THE ECONOMIC OPTIMAL IRRIGATION LEVEL FOR CORN PRODUCTION IN THE TEXAS PANHANDLE
}

\author{
W. Arden Colette, Clay Robinson, and Lal Khan Almas \\ Division of Agriculture, West Texas A\&M University \\ Canyon, Texas 79016
}

\begin{abstract}
Corn yield and evapotranspiration (ET) data obtained from weighing lysimeters is accumulated from nine experiments over six years and used to estimate a response function. The quadratic response function of corn yield as a function of water use by the plants indicates that yield increases at a decreasing rate as ET increases. Extending the analysis to water application data by commercial producers in a thirteen county area in the Texas Panhandle provides a response function of yield as a function of water application to meet ET needs. The best estimate of the relationship is a quadratic function. The response function is transformed into a value function measuring the value of corn produced corresponding to different levels of water availability. The cost function is estimated in terms of the energy cost for irrigation. These value and cost functions are then used to determine the profit maximizing level of water application for various price levels for corn and natural gas.
\end{abstract}

Key Words: response function, water, natural gas, input use, optimization.

\section{Introduction}

Texas agriculture generated over $\$ 13$ billion in receipts in 1999. Although the High Plains represents less than $15 \%$ of the area it accounts for over $40 \%$ of the value of agricultural production for the state. Agricultural is the largest industry in the High Plains region. In addition to leading the state in the production of corn, wheat, and cotton; more than 6 million cattle are fed annually within 75 miles of Amarillo (Texas Agricultural Statistics Service 2000).

Irrigation is important to maintaining the agricultural productivity in the area. District 1-N, the Northern High Plains, produces $60 \%$ of the corn and $88.6 \%$ of the irrigated corn in the state. Over half, $53.7 \%$, of the wheat including $88.4 \%$ of the irrigated wheat and $56.9 \%$ of the irrigated sorghum in the state is produced in District 1-N. The development of irrigation in the region is a recent phenomenon. Virtually all of the development has occurred since the end of World War II. Between 1950 and 1980 irrigated acres increased from 19,315 to 1,754,560. Since 1980 irrigated acres have declined to $1,363,438$ (Table 1). The water availability in the Ogalalla aquifer has declined and pumping costs have increased. The significance of the impact of irrigation in agricultural production is shown by the differential between the yield of irrigated and non-irrigated corn. In 1999, the yield on the 757,500 acres of irrigated corn averaged 180.4 bushels per acre, compared to an average of 40.0 bushels per acre on the 6,500 acres of nonirrigated corn (Texas Agricultural Statistics Service 2000). Irrigation increases yield by 2 to 7 times over non-irrigation. When risk is defined as a function of the variability in yield, irrigation reduces risk by $75 \%$ to $90 \%$. 
Due to the variability in precipitation irrigation is essential to maintaining consistent, high yields of corn in the Northern High Plains. In Amarillo the annual average precipitation over the 120year period from 1880 through 2000 is 20.53 inches. However, the range in annual precipitation is from less than 9 inches to over 40 inches (Figure 1). There are pronounced year-to-year variations with as much as 15 to 20 inch differences in consecutive years. Major wet and dry cycles are observed. Short periods of significantly above average precipitation are usually followed by long periods of below average to average precipitation. A seasonal pattern adds to the variability (Figure 2). Over 50\% of the annual precipitation is received during the summer growing season from May through October. May, June and August are the months with the highest average rainfall.

The decline in the water level in the Ogalalla aquifer is an on-going concern. Wells that produced 1000 to 1200 gallons per minute in the 1960's often produced less than 200 gallons per minute in the 1990's. Since there is almost no recharge of the Ogalalla aquifer in this area, irrigation water is a fixed supply. Any water applied in excess of the amount used by the crop is wasted and cannot be replaced. Excessive pumping results in shortening the economic life of the farming operation and reduces the returns to the resources held by the farmer (Amosson et al. 2001). This last year natural gas prices increased from less than $\$ 3$ per mcf (thousand cubic feet) to more than $\$ 11$ in less than six months. The rapid increase in natural gas prices during the energy crisis led to increased fears over the cost of irrigation and fertilizer. Natural gas is the primary energy source used for pumping irrigation water in the Texas Panhandle. Tripling of energy cost is prompting producers to ask whether they should abandon irrigation, switch to more water efficient crops, or reduce water application rates. This paper attempts to provide one answer to the question of how much water should be applied to corn in the Texas Panhandle. Producers tend to apply inputs in an effort to maximize output. Unfortunately, this will seldom result in the producer making the most profit. The Law of Diminishing Marginal Returns states that each additional unit of input provides a smaller increment in output than the preceding unit of input (Beattie and Taylor, 1985). Therefore, the producer will always reach a point where adding more input will increase cost by more than the increase in revenue. This will result in a decrease in the net retained by the producer. Profits will decline. Since the input level that maximizes profit will always be less than the level of input that maximizes output, the question is what level of input is the optimal economic level that will maximize profit for the producer. This study is an attempt to determine the optimal economic level of irrigation water application on corn with a Low Elevation Spray Application (LESA) system under different prices for corn and natural gas in the Texas Panhandle.

\section{Estimation of the Association of the Yield of Corn to Evapotranspiration}

It is necessary to determine the water response function for corn before the optimal water application rate can be determined. The response function shows the relationship between the yield and the amount of water used by the plant. It indicates the expected output level for each level of water application. It also provides the information on what the expected increase in yield will be if another unit of the input is used. 
The response function shows the relationship between the yield and the amount of water used by the plant rather than the amount of water applied. The output or yield is determined by the amount of water actually used in the biological growth process rather than the amount added to the field. The water use includes the water used by the plant in transpiration and the water lost from the soil through evaporation. Together these two processes are referred to as evapotranspiration (ET). Transpiration includes the water used by the plant for metabolism. Evaporation includes the water loss from plant and soil surfaces.

Data for estimating the water response function for corn includes 161 observations compiled from nine experiments conducted over a six-year period at the Bushland Agricultural Research Station west of Amarillo, TX (Howell et al. 1996; Howell et al. 1998; Tolk, Howell and Evett 1998). The water use and corresponding yields were measured using a weighing lysimeter. The data were combined into a single data set and linear, quadratic, square root, natural log, and Cobb-Douglas type functional forms were estimated using the SAS procedure, PROC GLM (SAS Institute Inc. 1999). Dummy variables were included to account for the exogenous variables associated with the different experiments. A quadratic model, such as in Equation 1, provides the best explanation for the relationship between the yield of corn and the water used for ET. This functional form allows for yield to increase at a decreasing rate as the level of ET increases. As the level of input increases, yield reaches a maximum and then declines. This fits very well with the biological processes.

$$
Y=b_{0}+b_{1} E T+b_{2} E T^{2}
$$

The quadratic model estimated from the data provides a statistically significant explanation for the relationship as $\left.\operatorname{Pr}>\mathrm{F}_{(2.150)}\right)<0.0001$ for the model. The $\mathrm{R}^{2}$ of 0.7305 indicates that over $73 \%$ of the variability in yield of corn can be explained by the variability in ET. The estimated function for the ET terms in shown in Equation 2. The probability of a greater $t$ is in parentheses below the coefficients.

$$
\begin{aligned}
Y= & -181.75+17.61 E T-0.158 E T^{2} \\
& (<0.0001)(<0.0001)(0.0047)
\end{aligned}
$$

The corn yield ET response function is overlaid on the scatter plot in Figure 3.

\section{Response Function for ET Water Applied}

ET is a measurement of the water needs of the plant and is determined by biological and climatic factors. Since the producer has no control over the level of ET it cannot be considered a management factor. The ET requirement is based on Reference Evapotranspiration $\left(\mathrm{ET}_{0}\right)$ adjusted to reflect the demands of the specific crop. The reference evapotranspiration is adjusted by multiplying by the specific crop coefficient $\left(\mathrm{K}_{\mathrm{C}}\right)$ which reflects biological factors such as the 
crop, maturity rating, and the growth stage; and climatic conditions such as maximum and minimum temperatures, growing degree days (GDD-56 ${ }^{\circ} \mathrm{F}$ ), humidity, solar radiation, wind speed, etc. Three sources of water to meet the ET requirement include residual soil moisture, natural precipitation, and irrigation. A producer has control over only one of these, irrigation. ET can be an aid to management decision making by indicating the amount of water that is needed by the plant. Applying water so that the ET requirement is just satisfied minimizes excessive application and subsequent water loss.

Scheduling the timing and amount of water to apply based on the ET requirement of the crop is the basis of the AgriPartners Irrigation Demonstration Project (New 2000). Participants in this program are provided daily information on climatic conditions and the ET requirements for their principle crops (Table 2). The producer then applies the amount of irrigation water needed to eliminate the ET deficit. Data collected from cooperators provided 66 observations of irrigation water application and the resulting corn yield. The observations represented producers in thirteen counties over a three-year period, 1998 through 2000 (New 2001).

Several functional forms were estimated to identify the best explanation of the relationship between corn yield and water applied to meet ET requirements. Functional forms estimated include linear, quadratic, square root, natural log, and Cobb-Douglas type functions. Dummy variables were included for county and year to account for the exogenous factors associated with site and time. The quadratic form produces the best explanation of the relationship between corn yield and water application to meet ET requirements with a $\operatorname{Pr}>\mathrm{F}_{(2.48)}<0.0001$ for the model. 'The $\mathrm{R}^{2}$ is 0.3745 . The estimated coefficients for the terms representing water application are shown in Equation 3. The $\operatorname{Pr}>t_{(48)}$ is in parentheses below the coefficients.

$$
\begin{aligned}
Y= & -59.37+10.66 W-0.127 W^{2} \\
& (0.2675)(0.0004)(0.0021)
\end{aligned}
$$

The quadratic function is plotted on a scatter diagram of the observed yields in Figure 4 . The yield increases at a decreasing rate as water availability increases. The maximum yield is reached at an availability of 41.97 inches.

\section{Optimal Economic Level of a Productive Input}

Determination of the optimal economic level of a productive input is based on the principle of profit maximization (Beattie and Taylor 1985). Profit is maximized at that input level where the increase in value from using an additional unit of input is equal to the increase in cost associated with the use of that same unit of input. The increase in value derived from the use of an additional unit of input is referred to as the Marginal Value Product (MVP). The MVP is equal to the increase in output obtained from the use of an additional unit of input [Marginal Physical Product (MPP)] multiplied by the price of the output. The increase in cost associated with the use of an additional unit of input is referred to as the Marginal Factor Cost (MFC). Therefore the 
optimal economic level of input use is determined where MVP=MFC.

The Marginal Physical Product of Water $\left(\mathrm{MPP}_{\mathrm{W}}\right)$ is equal to the derivative of the response function with respect to the input water $\left(\mathrm{MPP}_{\mathrm{W}}\right)$ (Equation 4).

$$
M P P_{W}=\frac{d Y}{d W}=10.66-0.254 W
$$

The Marginal Value Product of water $\left(\mathrm{MVP}_{\mathrm{W}}\right)$ is obtained by multiplying the Marginal Physical Product of water $\left(\mathrm{MPP}_{\mathrm{W}}\right)$ by the price of the product $\left(\mathrm{P}_{\mathrm{Y}}\right)$ (Equation 5).

$$
\begin{gathered}
M V P_{W}=M P P_{W} * P_{Y} \\
M V P_{W}=(10.66-0.254 W) P_{Y}
\end{gathered}
$$

The cost of production is the sum of the fixed cost and the variable input cost incurred in the production process. The fixed cost is a constant and independent of the amount of water applied. The variable input cost is directly associated with the level of irrigation (Equation 6). The variable input cost associated with the level of irrigation is made up of the fuel cost; cost of lubrication, maintenance, and repairs; labor costs; and annual investment costs (Almas et al. 2000).

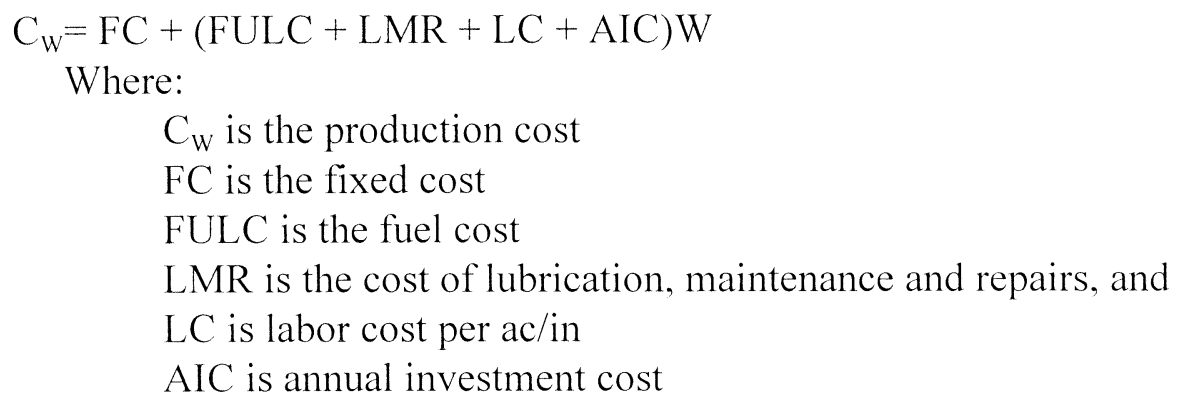

The impact of a change in the price of fuel is observed in the change in the cost of fuel. Since natural gas is the predominate source of energy for pumping irrigation water in the area, natural gas is used in the calculations. The fuel cost (FULC) is equal to the product of the amount of fuel used $(\mathrm{NG})$ multiplied by the price of the fuel $\left(\mathrm{P}_{\mathrm{NG}}\right)$ (Equation 7).

$$
\mathrm{FULC}=\mathrm{NG}^{*} \mathrm{P}_{\mathrm{NG}}
$$

In turn the amount of natural gas needed to pump and deliver one inch of water depends on the 
efficiency of the system, the lift required to get the water from below the ground to the delivery system, and the pressure of the delivery system (Equation 8).

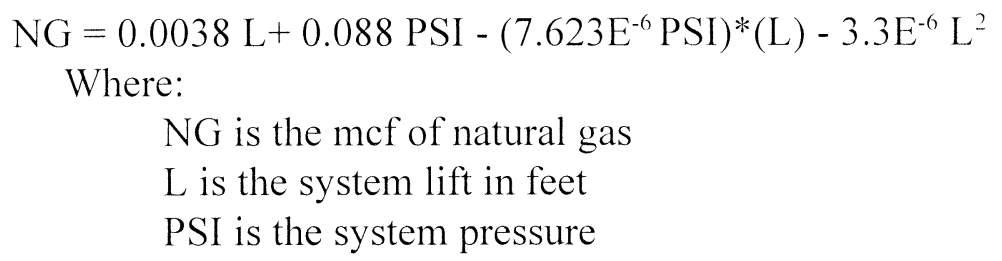

For a given irrigation system, such as a Low Elevation Spray Application (LESA) system with a 350 foot system lift; NG, LMR, LC and AIC are known constants (Almas et al. 2000). Therefore the Total Cost function for this system can be expressed as Equation 9.

$$
\mathrm{C}_{\mathrm{W}}=\mathrm{FC}+\left(1.018 \mathrm{P}_{\mathrm{NG}}+2.03+0.68+1.92\right) \mathrm{W}
$$

The Marginal Factor Cost of water $\left(\mathrm{MFC}_{\mathrm{W}}\right)$ can now be calculated from the cost function. The $\mathrm{MFC}_{\mathrm{W}}$ is the first derivative of the cost function with respect to the input, water $(\mathrm{W})$ (Equation 10).

$$
\begin{aligned}
M F C_{W} & =\frac{d C_{W}}{d W} \\
M F C_{W} & =1.018 P_{N G}+2.03+0.68+1.92 \\
M F C_{W} & =1.018 P_{N G}+4.63
\end{aligned}
$$

The Optimum level of the input water application can now be determined by equating the Marginal Value Product of water $\left(\mathrm{MVP}_{\mathrm{W}}\right)$ from Equation 5 and the Marginal Factor Cost of water $\left(\mathrm{MFC}_{\mathrm{W}}\right)$ from Equation 10.

$$
\begin{aligned}
& \mathrm{MVP}_{\mathrm{W}}=\mathrm{MFC}_{\mathrm{W}} \\
& (10.66-0.254 \mathrm{~W}) \mathrm{P}_{\mathrm{Y}}=1.018 \mathrm{P}_{\mathrm{NG}}+4.63
\end{aligned}
$$

Solving for the level of water availability (W) produces a function in the price of natural gas $\left(\mathrm{P}_{\mathrm{NG}}\right)$ and the price of the output $\left(\mathrm{P}_{\mathrm{Y}}\right)$ (Equation 12). 


$$
W=\frac{10.66-\frac{1.018 P_{N G}+4.63}{P_{Y}}}{0.254}
$$

\section{Affect of Changes in Energy Prices on the Optimum Level of Water Use}

The profit maximizing level of water use for ET can be determined for this LESA system for any combination of natural gas and corn prices (Equation 12). Optimal water availability for natural gas prices between $\$ 2$ and $\$ 10$ per mcf and corn prices between $\$ 1.50$ and $\$ 4$ per bushel are shown in Table 3. Following across any row in the table it is evident that the amount of water to apply increases as the price of corn increases for a fixed price of natural gas. Conversely, looking down any of the columns it can be seen that for a fixed price of corn the optimal water application rate declines as the price of natural gas increases. For example, at a price of $\$ 2$ per bushel for corn up to 28.8 inches of water can be used profitably when the natural gas price is $\$ 2$ per mcf. At these prices profits are maximized when 28.8 inches of water are available for ET. When the price of natural gas is $\$ 10$ per mcf only 12.8 inches of water can be applied economically.

\section{Summary}

Often the answers to management decision problems cannot be found in individual, controlled experiments. As in the case of developing the response function for corn to the availability and use of water, it is necessary to aggregate data from several experiments to be able to estimate the underlying relationship. Corn yield and ET data is accumulated from nine experiments over six years and used to estimate a quadratic response function of corn yield as a function of water use.

Developing relationships that are usable under commercial management conditions are even more challenging. Collecting adequate observations to estimate management decision functions for commercial producers is even more complicated. Fortunately the participation of progressive producers in a thirteen county area in the Texas Panhandle in the AgriPartners Irrigation Demonstration Project allows access to the needed information to estimate a response function relating corn yield as a function of water availability to meet ET needs. Introduction of the price for corn transforms the quadratic response function into a value function measuring the value of corn produced corresponding to different levels of water availability. The production cost will vary for different types of delivery systems and with different water lifts. For a given delivery system, such as LESA and a known lift the cost function can be expressed in terms of the energy cost. These value and cost functions are then used to determine the profit maximizing level of water availability for various price levels for corn and natural gas. As the price of corn increases producers will maximize their profits by increasing the availability of water increasing their production. On the other hand, as natural gas prices increase producers will maximize their 
profits by decreasing the use of energy, reducing water availability and use, and reducing production.

\section{References}

Almas, L.K., F. Bretz, S. Amosson, T. Marek, L. New, and B. Stewart. Determining Region A Water Supply Needs for the 50-year Planning Period. Panhandle Water Planning Project Task 4 Project Memorandum. Texas A\&M University, Agricultural Research and Extension Center, Amarillo, Texas, April 2000.

Amosson, S.H., L. Almas, L. New, and F. Bretz. Economics of Alternative Irrigation Systems.' Texas Agricultural Extension Bulletin, 2001. (Forthcoming)

Beattie, B.R., and C.R. Taylor. The Economics of Production. John Wiley \& Sons 1985.

Howell, T.A., A.R. Evett, J.A. Tolk, A.D. Schneider, and J.L. Steiner. "Evapotranspiration of Corn - Southern High Plains." In C.R. Camp, E.J. Sadler, and R.E. Yoder (eds) Evapotranspiration and Irrigation Scheduling, Proceedings of the International Conference, Nov. 3-6, 1996, San Antonio, TX, American Society of Agricultural Engineers, St. Joseph, MI.

Howell, T.A., J.A. Tolk, A.D. Schneider, and S.R. Evett. "Evapotranspiration, Yield, and Water Use Efficiency of Corn Hybrids Differing in Maturity." Agron. J. 90:3-9 (1998).

New, L. AgriPartners Crop Irrigation and Production Summary, 1999. Texas Agricultural Extension Service, 2000.

New, L. “Corn Production per Inch of Water '98,'99,'00 AgriPartners." 2000 AgriPartner Summary, Texas Agricultural Extension Service, Texas A\&M University, 2001.

SAS Institute Inc., SAS/STAT ${ }^{\mathrm{k}}$ Users Guide, Version 8, Cary, NC: SAS Institute Inc., 1999.

Tolk, J.A., T.A. Howell, and S.R. Evett. "Evapotranspiration and Yield of Corn Grown on Three High Plains Soils." Agron. J. 90:447-454 (1998).

Texas Agricultural Statistics Service. Texas Agricultural Statistics Service 1999. Bulletin 258, September 2000. 
Table 1. Irrigated acres in Region A of the High Plains, by method of application, 1950 through 1997 (Almas et al. 2000).

$\begin{array}{rrrr}\text { Year } & \begin{array}{r}\text { Furrow } \\ \text { Irrigated }\end{array} & \begin{array}{r}\text { Sprinkler } \\ \text { Irrigated }\end{array} & \text { Total Acres } \\ 1950 & 19,315 & 0 & 19,315 \\ 1960 & 549,884 & 20,397 & 570,281 \\ 1970 & 1,379,878 & 137,139 & 1,517,017 \\ 1980 & 1,353,443 & 401,117 & 1,754,560 \\ 1990 & 676,051 & 515,195 & 1,191,246 \\ 1997 & 509,267 & 854,171 & 1,363,438\end{array}$

Figure 1. Annual precipitation and growing season precipitation reported at the Amarillo weather station from 1880 to 2000.

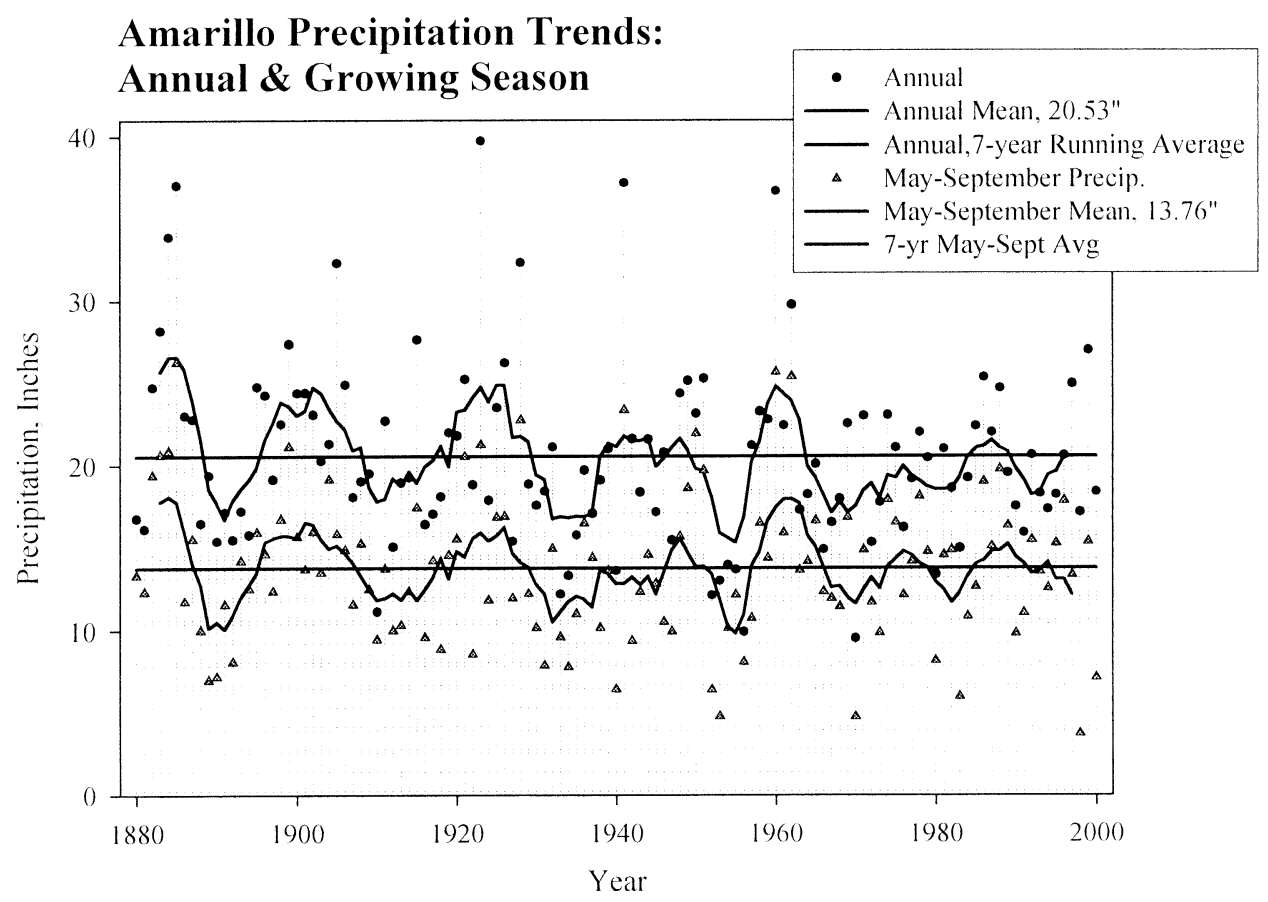


Figure 2. Average precipitation for each day of the year from historical weather data (62 years) collected at the USDA-ARS Research station at Bushland, Texas

\section{Precipitation Amount by Day of Year, Bushland, TX}

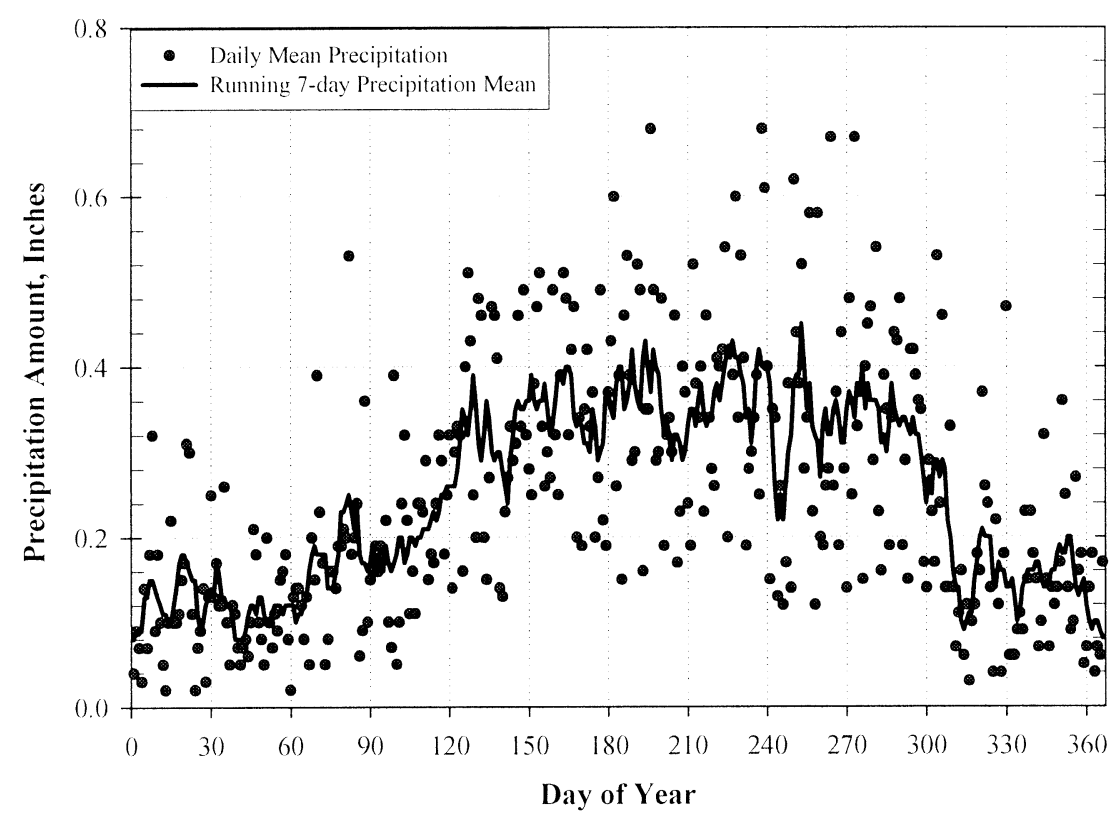

Figure 3. Response function for corn yield to evapotranspiration

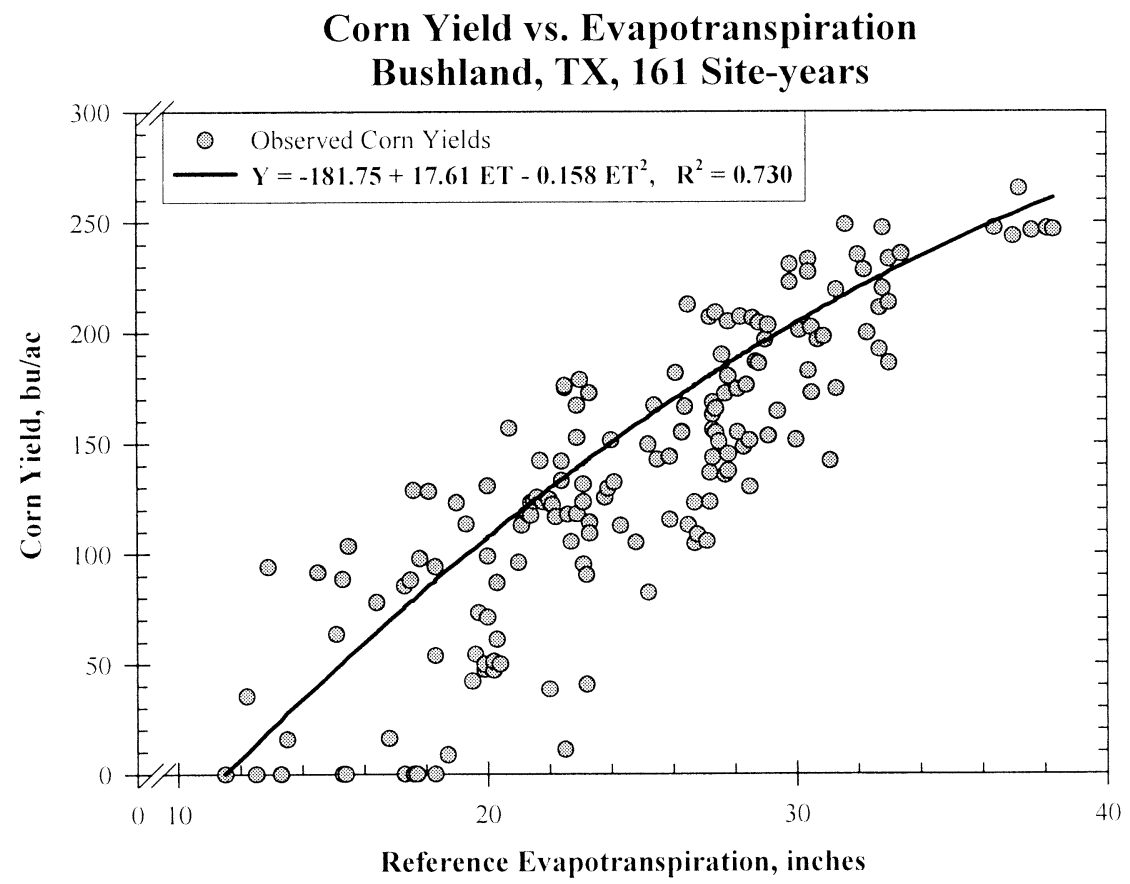


Table 2. Daily ET requirement and climatic information available to AGRIPARTNER participants through the North Plains Network.

North Plains $\mathrm{ET}_{0}{ }^{a}$ Network Weather Station, Dalhart, TX

$$
\text { Temperatures (F) }
$$

Date $\quad \mathrm{ET}_{0}{ }^{\mathrm{a}}{ }^{----A i r---}$ Soil Min Prec Growing Degrees Days (F)

In. Max Min 2in 6in in Crn Srg Pnt Cot Soy Wht

$\begin{array}{lllllllllllll}07 / 28 / 2000 & .25 & 95 & 61 & 74 & 82 & 0.00 & 23 & 28 & 23 & 18 & 27 & 0\end{array}$

$\begin{array}{lllllllllllll}07 / 29 / 2000 & .24 & 87 & 62 & 76 & 83 & 0.00 & 24 & 25 & 20 & 15 & 28 & 0\end{array}$

$\begin{array}{lllllllllllll}07 / 30 / 2000 & .21 & 87 & 59 & 74 & 82 & 0.00 & 23 & 23 & 18 & 14 & 27 & 0\end{array}$

10-day avg min soil temp $72 \quad 80 \quad$ Wind $3.0 \mathrm{mph}$ from $66 \mathrm{deg}$.

CORN Short Season Var. Water Use Long Season Var. Water Use

Seed Acc Growth Day 3day 7day Seas Growth Day 3day 7day Seas

Date GDD Stage -----in/d----- in. Stage -----in/d----- in.

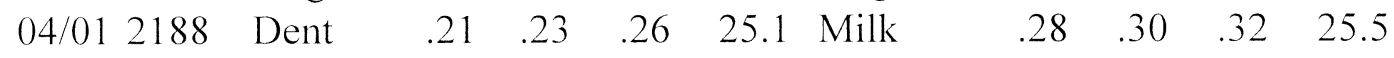

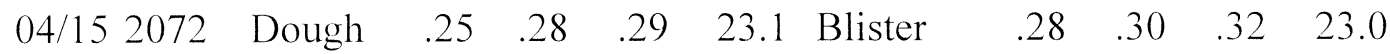

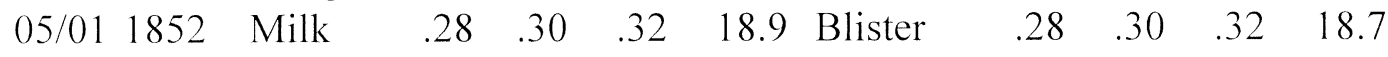

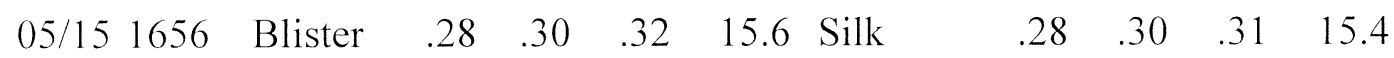

${ }^{a} \mathrm{ET}_{0}$ (Reference Evapotranspiration) is the amount of water used by a well watered grass crop that is kept at a 2 inch height. It is adjusted to $\mathrm{ET}_{\mathrm{C}}$ (Crop Evapotranspiration) by multiplying by the crop coefficient for that crop.

Figure 4. Response function for corn yield to availability of water based on ET requirements.

Corn Yield vs. Water Used

\section{Texas Panhandle Counties, 66 Site-years}

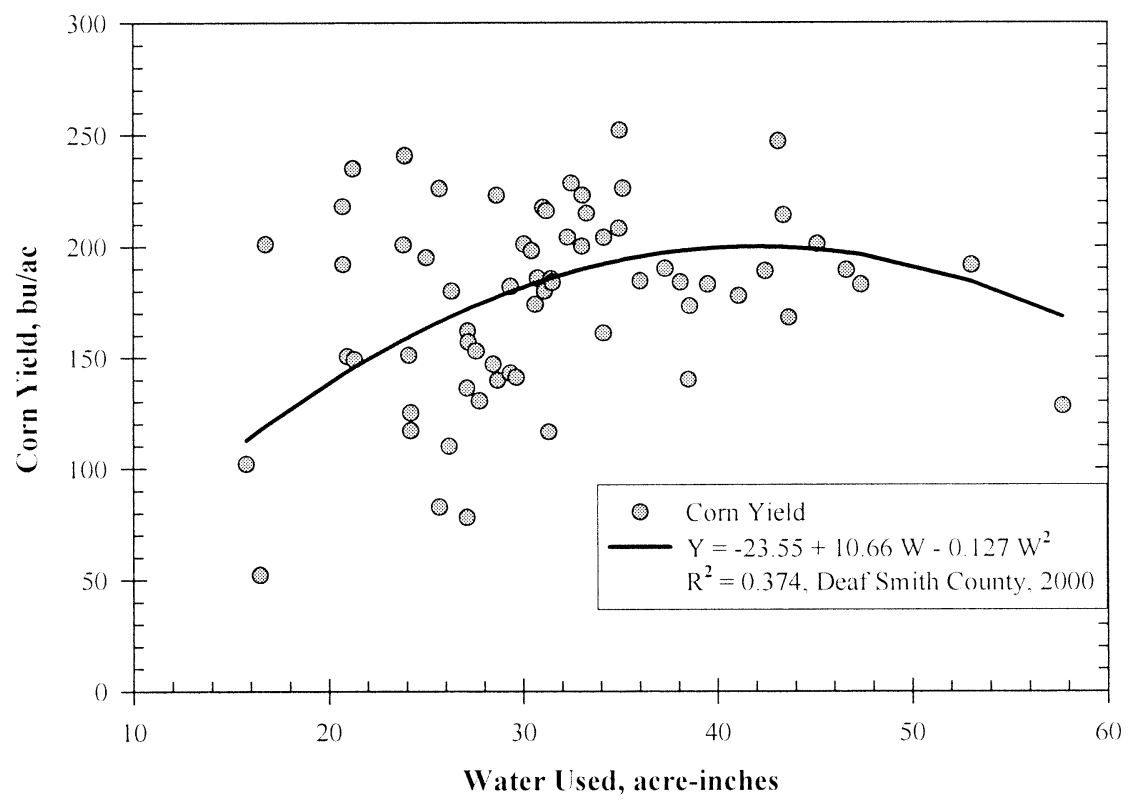


Table 3. Optimum water availability for meeting ET requirements under different corn prices and natural gas prices.

\begin{tabular}{ccccccccccc} 
& & \multicolumn{8}{c}{$\mathrm{P}_{Y}$} \\
$\mathrm{P}_{\text {NG }}$ & 1.50 & 1.75 & 2.00 & 2.25 & 2.50 & 2.75 & 3.00 & 3.25 & 3.50 & 4.00 \\
\cline { 2 - 10 } 2.00 & 24.5 & 27.0 & 28.8 & 30.3 & 31.5 & 32.4 & 33.2 & 33.9 & 34.5 & 35.4 \\
2.50 & 23.1 & 25.8 & 27.8 & 29.4 & 30.7 & 31.7 & 32.6 & 33.3 & 33.9 & 34.9 \\
3.00 & 21.8 & 24.7 & 26.8 & 28.5 & 29.9 & 31.0 & 31.9 & 32.7 & 33.3 & 34.4 \\
3.50 & 20.5 & 23.5 & 25.8 & 27.6 & 29.1 & 30.2 & 31.2 & 32.0 & 32.8 & 33.9 \\
4.00 & 19.1 & 22.4 & 24.8 & 26.7 & 28.3 & 29.5 & 30.5 & 31.4 & 32.2 & 33.4 \\
4.50 & 17.8 & 21.2 & 23.8 & 25.9 & 27.5 & 28.8 & 29.9 & 30.8 & 31.6 & 32.9 \\
5.00 & 16.5 & 20.1 & 22.8 & 25.0 & 26.7 & 28.1 & 29.2 & 30.2 & 31.0 & 32.4 \\
5.50 & 15.1 & 19.0 & 21.8 & 24.1 & 25.9 & 27.3 & 28.5 & 29.6 & 30.5 & 31.9 \\
6.00 & 13.8 & 17.8 & 20.8 & 23.2 & 25.1 & 26.6 & 27.9 & 29.0 & 29.9 & 31.4 \\
6.50 & 12.4 & 16.7 & 19.8 & 22.3 & 24.3 & 25.9 & 27.2 & 28.3 & 29.3 & 30.9 \\
7.00 & $-\mathrm{a}$ & 15.5 & 18.8 & 21.4 & 23.5 & 25.1 & 26.5 & 27.7 & 28.7 & 30.4 \\
7.50 & - & 14.4 & 17.8 & 20.5 & 22.7 & 24.4 & 25.9 & 27.1 & 28.2 & 29.9 \\
8.00 & - & 13.2 & 16.8 & 19.6 & 21.9 & 23.7 & 25.2 & 26.5 & 27.6 & 29.4 \\
8.50 & - & 12.1 & 15.8 & 18.7 & 21.1 & 23.0 & 24.5 & 25.9 & 27.0 & 28.9 \\
9.00 & - & - & 14.8 & 17.8 & 20.2 & 22.2 & 23.9 & 25.3 & 26.5 & 28.4 \\
9.50 & - & - & 13.8 & 16.9 & 19.4 & 21.5 & 23.2 & 24.6 & 25.9 & 27.9 \\
10.00 & - & - & 12.8 & 16.1 & 18.6 & 20.8 & 22.5 & 24.0 & 25.3 & 27.4
\end{tabular}

"Values not determinable, outside the range of observations. 